\title{
SITE SELECTION OF A GEOLOGICAL REPOSITORY FOR THE SAFE DISPOSAL OF HIGH-LEVEL WASTE IN THE STATE OF RIO DE JANEIRO
}

\author{
LOCALIZAÇÃO DE REPOSITÓRIOS GEOLÓGICOS \\ PARA A DEPPOSIÇÃO DE REJEITOS RADIOATIVOS DE \\ ALTO NÍVEL NO ESTADO DO RIO DE JANEIRO
}

\author{
Corbiniano Silva \\ Departamento de Geologia/UERJ \\ Monica da Costa Pereira Lavalle Heilbron \\ Departamento de Geologia/UERJ \\ Paulo Fernando Lavalle Heilbron Filho \\ Comissão Nacional de Energia Nuclear
}

\begin{abstract}
The choice of candidates sites for final disposal of high-level radioactive wastes has been a complicated process worldwide, mainly due to the complexity of the environments that are adequate to receive this type of repositories, whose disposal may have several implications related to environmental impacts, as well as in a set of issues associated to the geographical dynamics of these regions. In the Brazilian case, where the nuclear program includes the operation of two nuclear power plants and a third unity under construction, the concern with the high-level nuclear waste is still in its infancy. However, it is important that studies be discussed and started,including the development of methodologies that can contribute to the implementation of policies, rules and specific regulations, in order to facilitate an action planning for the solution of this problem. Thisarticlewill show part of the studies that are being conducted by some Brazilian Nuclear Energy Commission (CNEN) experts together with some professors from the State University of Rio de Janeiro (UERJ), regarding site selection of deposits for high-level radioactive waste in the state of Rio de Janeiro. The work will focus, especially, on geological repositoriesaimed for the safe disposal of the high-level radioactive waste produced mainly by the Brazilian nuclear plants Angra 1,2 and 3 located in the state. This article will also point out the main aspects involved on the technical choice process necessary for this kind of deposits, including the present stage of research for the development of a database, based on a geographic information system (GIS). This GIS system will containtechnical information to support the decision making process of site selection, establishing geo-environmental guidelines including the development of a specific methodology for site selection.
\end{abstract}

Keywords:High level waste, geological repositories, database, GIS. 


\section{RESUMO}

A escolha de locais para a deposição definitiva de rejeitos radioativos de alto nível tem sido um processo complicado em todo o mundo, sobretudo em função da complexidade dos ambientes que são propícios para receber este tipo de passivo, cujas características tem implicações diversas, onde se destacam os impactos ambientais, além de um conjunto de questões que envolvem a dinâmica geográfica desses locais. No caso brasileiro, cujo parque nuclear atualmente possui 2 usinas, tendo uma terceira em construção, a preocupação com os rejeitos nucleares de alto nível é ainda incipiente. Contudo, torna-se fundamental que sejam discutidos e iniciados estudos visando o desenvolvimento de metodologias que possam contribuir para a implementação de políticas, normas e regulamentações no sentido de viabilizar o planejamento de ações para este fim. O estudo mostra a importância da escolha de locais, sobretudo repositórios geológicos situados no estado do Rio de Janeiro para a deposição dos rejeitos radioativos de alto nível produzidos pelas usinas de Angra 1 e 2, apontando perspectivas sobre os caminhos para sua escolha, onde se incluem diretrizes geoambientais, a elaboração de metodologias específicas e um banco de dados baseado em sistemas de informação geográfica (SIG).

Palavras-Chave: Rejeitos radioativos de alto nível, repositórios geológicos, banco de dados, SIG.

\section{INTRODUCTION}

Industrial, medical and research installations that involve radioactive materials generate wastes that must be properly managed. The waste containing radionuclides under some levels of radioactivity is named radioactive waste (RW).

The establishment of exempt limits to classify something as radioactive waste is because the radioactivity is in everywhere. The humankind has always lived in a radioactive environment. The human body also contains radioactive elements $(\mathrm{C}-14, \mathrm{~K}-$ 40, etc.) and life on planet Earth has always been subject to radiation from cosmic rays and from radioactive elements present in rocks, soil, water, food and air. The radiation to which we are all exposed is known as background radiation.

Unlike other types of hazardous waste, radioactive wastes transforms (decays) with time. Some known as very short-lived radioactive waste loses its radiation dangerous properties rapidly, due to radioactive decay, becoming stable nuclides, which allows sometimes its immediate release in the environment as conventional waste.

The International Atomic Energy Agency (IAEA) published in 2009 a document named General Safety Guide GSG-1 - IAEA (2009), which classifies radioactive waste into six categories, as shown in Table 1. 
According to the radiological characteristics of the radioactive waste sometimes,they can be cleared immediately to the environment and treated as general garbage (exempt waste). Sometime they can be sent to countries of origin to be reused (not considered waste) and sometimes they can be stored for a period of time until they can be released to the environment (when they cease to be dangerous) (VSLW) and sometime must be deposited definitely in repositories (LLW, ILW and HLW), as shown in Table 1.

Table 1. Classification of Radioactive Wastes (IAEA).

\begin{tabular}{|c|c|}
\hline Category & Characteristics \\
\hline ExemptWaste (EW) & $\begin{array}{l}\text { Waste that meets the criteria for clearance, exemption or exclusion from regulatory } \\
\text { control for radiation protection purposes }\end{array}$ \\
\hline $\begin{array}{l}\text { Very Short Lived Waste } \\
\text { (VSLW) }\end{array}$ & $\begin{array}{l}\text { Waste that can be stored for decay over a limited period of up to a few years and } \\
\text { subsequently cleared from regulatory control according to arrangements approved } \\
\text { by the regulatory body, for uncontrolled disposal, use or discharge. This class } \\
\text { includes waste containing primarily radionuclides with very short half-lives often } \\
\text { used for research and medical purposes. }\end{array}$ \\
\hline $\begin{array}{l}\text { Very Low Level Waste } \\
\text { (VLLW) }\end{array}$ & $\begin{array}{l}\text { Waste that does not necessarily meet the criteria of EW, but that does not need a } \\
\text { high level of containment and isolation and, therefore, is suitable for disposal in } \\
\text { near surface landfill type facilities with limited regulatory control. Such landfill type } \\
\text { facilities may also contain other hazardous waste. Typical waste in this class } \\
\text { includes soil and rubble with low levels of activity concentration. Concentrations of } \\
\text { longer-lived radionuclides in VLLW are generally very limited. }\end{array}$ \\
\hline LowLevelWaste (LLW) & $\begin{array}{l}\text { Waste that is above clearance levels, but with limited amounts of long-lived } \\
\text { radionuclides. Such waste requires robust isolation and containment for periods of } \\
\text { up to a few hundred years and is suitable for disposal in engineered near surface } \\
\text { facilities. This class covers a very broad range of waste. LLW may include short- } \\
\text { lived radionuclides at higher levels of activity concentration, andlong-lived } \\
\text { radionuclides, but only at relatively low levels of activity concentration. }\end{array}$ \\
\hline $\begin{array}{l}\text { IntermediateLevelWaste } \\
\text { (ILW) }\end{array}$ & $\begin{array}{l}\text { Waste that, because of its content, particularly of long-lived radionuclides, requires } \\
\text { a greater degree of containment and isolation than that provided by near surface } \\
\text { disposal. However, ILW needs no provision, or only limited provision, for heat } \\
\text { dissipation during its storage and disposal. ILW may contain long-lived } \\
\text { radionuclides, in particular, alpha emitting radionuclides that will not decay to a } \\
\text { level of activity concentration acceptable for near surface disposal during the time } \\
\text { for which institutional controls can be relied upon. Therefore, waste in this class } \\
\text { requires disposal at greater depths, of the order of tens of meters to a few hundred } \\
\text { meters. }\end{array}$ \\
\hline High LevelWaste (HLW) & $\begin{array}{l}\text { Waste with levels of activity concentration high enough to generate significant } \\
\text { quantities of heat by the radioactive decay process or waste with large amounts of } \\
\text { long-lived radionuclides that need to be considered in the design of a disposal } \\
\text { facility for such waste. Disposal in deep, stable geological formations usually } \\
\text { several hundred meters or more below the surface is the generally recognized } \\
\text { option for disposal of HLW. }\end{array}$ \\
\hline
\end{tabular}

The IAEA classifies the radioactive repositories into two categories as follows:

(A) Near Surface Repositories

(B) Geological repositories

A near surface repository is constructed at a distance of a few meters from the surface (not greater than 30 meters) and can be either a simple trench or a more sophisticated construction with engineering barriers, usually made by concrete. This kind of final disposal deposit has been used by many countries for the safe disposal of their low level waste (LLW), including Brazil (GOIÂNIA), England (DRIGG), France (LA 
MANCHE and CENTRE DE L'AUBE), Canada (IRUS), Japan (ROKKASHO), Spain (EL CABRIL), Sweden (OSKARSHAMN) and USA (BARNWELL).

The establishment of an institutional period of control for near surface repositories is very important in order to diminish the risks of intrusion in the long term that could lead to higher doses for the intruder. The institutional period can be passive (without the presence of personnel in the site) or active (with personnel in the site for the purpose of monitoring and physical protection, among other activities).

In Brazil this kind of deposit was used for the safe disposal of the radioactive waste generated in the city of Goiânia, as consequence of the cleanup activities of the contaminated city with radioactive material due to an accident that occurred in 1987 involving the stolen and violation of a teletherapy equipment with a Cs-137 radioactive source, according Heilbron et al (1994) andHeilbron et al (1996).

Geological disposal facility is recommended for high and intermediate level waste and can belong to one of the following categories:

(1) Cavities specially constructed by man;

(2) Old abandoned salt mines; and

(3) Natural cavities.

The types of geological repositories planned in the world are shown in Table 2.It can be seenfrom Table 2 that the choice of location and the decision on the construction of geological repositories is a very complex issue. In Brazil, there is no study or rule on the choice of locations for deposits of radioactive high-level waste showing the importance of this work.

Table 2. Planning repositories in the world for high-level waste.

\begin{tabular}{lcc}
\hline \multicolumn{1}{c}{ Country } & Type & Year \\
\hline \hline German & Salt Formation & 2030 \\
Belgium & Clay Formation & 2025 \\
Canada & Cristaline Rocks & 2010 \\
France & Manyoptions & 2025 \\
Sweden & Cristaline Rocks & 2017 \\
Switzerland & Cristaline Rocks & 2040 \\
China & Notestablished & 2040 \\
Eslovquia & Notestablished & 2037 \\
Eslovenia & Notestablished & 2066 \\
Spain & Notestablished & 2035 \\
Holand & Notestablished & After 2100 \\
Hungry & Notestablished & 2047 \\
Japan & Notestablished & 2035 \\
Romenia & Notestablished & 2049 \\
Brazil & No plans & - \\
Austria & No plans & - \\
Bulgary & No plans & - \\
England & No plans & -
\end{tabular}


Although there is no regulation in the country for site selection of sites for geological deposits, at international level there are a number of important documents on the subject, including those drawn up by the IAEA,111-G-4.1 (1994), IAEA WS-R-4 (2006), the main references to support this study.

It is noteworthy that the CNEN regulation CNEN-NE-6:06(CNEN, 1989) addresses some criteria's for the selection of locations for near surface deposits for low level waste and part of them can be applied for the choice of geological sites.

Considering that the activities involving the use of nuclear materials in their many process steps generate radioactive waste, they need to have an adequate destination where they can be contained, treated, and stored safely.

\section{PRINCIPLES FOR WASTE MANAGEMENT}

According to the IAEA -111-F (1995)the management of radioactive wastes must follow the nine principles listed below:

- P1: Protect human health.Radioactive waste shall be managed in such a way as to secure an acceptable level of protection for human health. Attention should be given to the many pathways of human exposure possibilities and all the radiological protection aspects are applied to the waste management and the long term risks calculations should take into consideration all the uncertainties involved;

- P2:Protection of environment. Radioactive waste shall be managed in such a way as to provide an acceptable level of protection of the environment. The waste generation amount shall be kept as low as possible. The preferred approach to radioactive waste is concentration and containment of radionuclides rather than dilution and dispersion in the environment;

- P3: Protection beyond national borders. This principle is based on ethical concerns for human health and the environment in other countries that is related to the premise that a country has a duty to act responsibly and, as a minimum, not impose effects on human health and in the environment more detrimental than those accepted in the own country;

- P4:Protect future generations. Radioactive waste shall be managed in such way that predicted impacts on the health of future generations will not be greater than relevant levels of impact that are acceptable today in the country. It is a fact that is not possible to ensure total isolation of the waste over long period of time that's 
way the objective of the waste management is to achieve reasonable assurance that there will be nounacceptable risk/impacts on human health. The approach for safety is the multi-barriers principle including suitable natural barriers and engineered barriers and shall also take into account the possibility of future explorations of the area in the search for valuable natural resources that could affect in long term the security of the repository;

- $\quad P 5: B u r d e n s$ on future generations. Radioactive waste shall be managed in such a way that will not impose undue burdens on future generation. Also an ethic principle. The generation that receive the benefits of the practice should bear the responsibility to manage adequate the resulting waste although in some especial cases some limited actions may be passed to succeeding generation such as environmental samples collection analysis during the institutional control period. It is also important that the management of the waste should not rely on long term institutional times and the location and inventory of radioactive waste disposed should be appropriately recorded and the records maintained;

- P6:National legal framework. Radioactive waste shall be managed within and appropriate national legal framework including clear allocation of responsibilities and provision for independent regulatory functions that means clear separation of the regulatory function, including enforcement, from the operating function in order to ensure safe operation of the installations and repositories;

- P7:Control and minimization of the waste generated. Generation of the waste should be kept to the minimum practicable by appropriate design measurements and decommission decisions including the correct selection of materials for possible recycle and reuse and through the implementation of adequate operating procedures;

- P8: Radioactive waste generation and management interdependencies. There are interdependencies among the different steps of waste management such pretreatment, treatment, conditioning, storage, transport and disposal. One wrong decision in one-step can effect badly the next step of action;

- P9:Safety of facilities. The safety of facilities for radioactive waste management shall be appropriately assured during their lifetime. During siting, design, construction, commissioning and closure of a repository priority needs to be given to safety issues including the prevention of accidents and mitigation if one occur.

\section{MAIN NUCLEAR INSTALLATIONS IN BRAZIL}


The main Brazilian installations that generates radioactive waste in the country are:

- Two nuclear power plants in operation and one under construction (Angra 1 is a 657 MWe gross/626 MW net, 2-loop PWR and Angra 2, 1345 MWe gross /1275MWe net, 4-loop PWR), all located in the Angra dos Reis City, Rio de Janeiro state. Angra 3 under construction will be a 1312 MWe gross/1229 MW net, 4-loop PWR and has had the construction temporarily interrupted since 1991 and in the year 2010 the construction begin again;

- Two uranium mine and milling operated by the Nuclear Brazilian Industry (INB), one closed and the other in operation. In Poços de Caldas city located in Minas Gerais state, a closed mine, has been operated from 1982 until 1991. All the economically recoverable Uranium has been extracted and currently no mining activity is under way. The Uranium treatment facility is still operational and has been used to process other source material from the second Brazilian mine, located in Caetité, Bahia state, with a capacity of treating $100 \mathrm{t} / \mathrm{y}$ of $\mathrm{U}_{3} \mathrm{O}_{8}$ and the production of Lanthanum Chloride and Cerium Hydroxide. The new mining facility (Caetité) has been operational since 2000 with reserves of 100.000 t of $\mathrm{U}_{3} \mathrm{O}_{8}$, and a capacity of 400 $\mathrm{t}$ /year of yellow cake $\left(\mathrm{U}_{3} \mathrm{O}_{8}\right)$, which can be expanded to $800 \mathrm{t} /$ year;

- One fuel element complex named FEC located in Rio de Janeiro state also operated by INB including a reconversion plant and a fuel fabrication plant. The enrichment plant is expected to be in operation in the year 2015;

- Four research reactors (the first and oldest in Latin America named IEA-R1 built in 1956 within the US Atoms for Peace program is located at the Nuclear and Energetic Research Institute (IPEN) belonging to CNEN, on São Paulo University campus, in São Paulo city, with a maximum power of $5 \mathrm{MW}$. The second named IPR-R1 is a $100 \mathrm{~kW}$ Triga reactor operating since 1960 at the Nuclear Technology Development Center (CDTN), also belonging to CNEN, located on the campus of Federal University of Minas Gerais in Belo Horizonte. The third Brazilian Nuclear Research reactor is named ARGONAUTA (1965)and also belongs to CNEN, is located at the Institute of Nuclear Engineering (IEN), on the campus of the Federal University of Rio de Janeiro, in Rio de Janeiro city, and can operate at a maximum power of $1 \mathrm{~kW} / \mathrm{h}$. The last one, named IPEN MB-01, is also located at IPEN and is a the result of a national joint program developed by CNEN and the Navy and is basic a water tank type critical facility rated $100 \mathrm{~W}$;

- A Pilot scale fuel cycle facilities, including a plant for the conversion of uranium to $\mathrm{UF}_{6}$ and another for uranium enrichment that belongs to the navy; 
- Approximately 3400 medical, industrial and research facilities that uses radioactive sources and equipments (not including x-rays);

- One industrial facility for processing of monazite sands, and;

- Many installations with NORM radioactive materials (phospates, zirconite, petroleum,tantalite, columbite, etc)

The high-level radioactive waste generated by nuclear power reactors, particularly those from the nuclear complex in Angra dos Reis - RJ as well as those arising from existing research reactors in Brazil are the main focus of this work.

The waste generated each year in Angra I and II nuclear plants and those that will be generated by Angra III, shall be deposited, in accordance with the international recommendations of the IAEA, in geological deposits, ie, at great depths, and the site of deposition should mandatorily followmany technical safety criteria's.

The basic objective of this type of repository is to isolate the waste from biosphere (contact with water and human intrusion for a long period).

In 2001, a specific Brazilian Waste Law was approved (Law 10,308)whose main articles emphasize the need for licensing all the waste deposits existing in the country as soon as possible, as shown below:

Art. 1.This law sets standards for the final disposal of radioactive waste produced in the country, including site selection, construction, licensing, operation, supervision, costs, damages, liability and security for radioactive waste deposits.

Art. 3.It is permitted the installation and operation of the following types of radioactive waste disposal sites:

i. Initial deposits (where the waste is generated - with the operator);

ii. Intermediate deposits (where the waste can be treated - CNEN institutes);

iii. Final repositories (where wastesare deposited unintentionally to retrieve).

As we saw earlier, these deposits are classifiedas near surface or geological deposits.

Art. 4. The initial deposits, intermediate and final will be built, licensed, managed and operated according to criteria, procedures and standards established by CNEN. It is prohibited receive in the final repositories radioactive waste in liquid or gaseous form.

$\S 1$. Initial deposits used for storing waste from mine and milling operations in the extraction site or ore processing can be converted into final repositories, with the express permission of CNEN.

$\S 2$. In the case of radiation accidents or nuclear exceptionally provisional deposits could be built, which will be disabled, with the total transfer of waste for interim storage 
or final disposal, according to criteria, procedures and rules specially established by CNEN.

Art. 6. The selection of sites for intermediate and final repositories facilities must meet the criteria, procedures and standards established by CNEN.

Sole paragraph. The selected land for final repositories will be declared of public utility and expropriated by the Union, when they are not of your property.

Art. 7. It is forbidden to deposit waste of any nature on oceanic islands, continental shelf and in Brazilian territorial waters.

It is noteworthy that, to date, the CNEN does not have a standard for site selection for geological deposits, particularly for the deposition of high-level waste.

\section{BASIC CRITERIA'S FOR THE SITE SELECTION OF REPOSITORIES FOR RADIOACTIVE WASTES}

As established in the Federal Law 4118 of 1962, Federal Law 6189 of 1974 and Federal Law 7781 of 1989 , CNEN is responsible, among other duties, for the receiving and disposing of radioactive waste in the country, as well as for issuing regulations and safety standards related to treatment and disposal of radioactive waste.

The complexity and costs involved in site selection, construction and safety assessment of a final disposal facility determine, globally, the policy to store low level radioactive waste in intermediate deposits to accumulate sufficient waste volume that justify this enterprise expenses as well as in the case of the high level waste storage them in the pools.

Irradiated fuel elements during operation of the power plants Angra I and II are stored in pools in their respective buildings of reactors, and waiting for a definition about the necessity of reprocessing or not (Political decision).

The Brazilian Nuclear Energy Commission (CNEN) is responsible for the development of regulation on safety analysis of waste disposal facilities, including the format of presentation, the nature and degree of detail of the information to be providedat each stage by the operator and the procedures for verification of the adequacy and quality of the information received.The safety standards of the International Atomic Energy Agency and other international recommendations should be taken into consideration whenever possible.

It is strongly necessary that CNEN urgently establish a comprehensive set of safety standards and requirements related with:

- The selection and choice of sites for high-level radioactive waste disposal; 
- The criteria for acceptance of high-level waste for final disposal; and

- Radiation protection criteria for evaluating the acceptability of the geological disposal facility.

Many interested documents can be found in the international literature regarding recommendations on this subject, particularly in two IAEA documents IAEA cited before and listed below:

- Siting of Geological Disposal Facilities (111-G-4.1), 1994, which is being revised;

- Geological Disposal of Radioactive Waste (WS-R-4), 2006.

- Predisposal Management of High Level Radioactive Waste (WS-G-2.6), 2003.

As shown before, CNEN published, in 1989, the regulation CNEN-NE-6.0.6that deals only with criteria's for selection of locations for near surface deposits for Low Level Radioactive Waste. It should be emphasized that nothing was established up to date for the site selection of geological repositories for the safe disposal of high-level waste in Brazil.

However, it can be seen that part of the criteria's established in the CNEN-NE6.0.6 regulation for the selection of near surface sites for low level waste disposal also apply for the selection of geological sites, such the establishment of four phases (steps) in different scales studies until reaches the selected area as follows:

- RegionofInterested;

- Preliminaryareas;

- PotentialAreas;

- Candidate Sites.

The regulation also established that during the selection process many technical experts must be involved including geologists, hydrologists, physicists, geographers, engineers, ecologists, biologists, radiation protection, meteorologists, chemistries, lawyers, etc.

Some established criteria's of the above-mentioned regulation repeated below also applies to the site selection of geological repositories such as:

- The site should be located preferably on public lands;

- The region of interest and the preliminary areas must be identified on a regional scale;

- Potential areas should be identified in semi detail scale;

- Local candidates must be identified in detail scale. 
The selection and choice of locations must comply with the technical analysis process, selectively and sequentially, comprising various levels of detail data and information.

A series of technical requirements has been established in the CNEN-NE-6.0.6 standard for regions of interest, including the need for ecological, socio-economic, geological and physiographic studies. In this way, specific consideration of each of these items should be included in the analysis.

Ecologicalstudies must include:

- Prevision of environmental impacts due to the repository operation in terms of its physical, chemical and biological components;

- Estimation of potential effects (beneficial and adverse) caused by the deposition of the waste at the site including changes in existing conditions locally and in the nearby field;

- Identification of the species and ecosystems.

Prior environmental impact study must be madeon the physical and biological environment, with the identification of existing ecosystems and ecological processes, comprisingthe following topics:

- Terrestrial Ecology and Aquatic- Estimation of the possible subsequent changes due to the construction and operation of the disposal facility;

- Protected Areas and Ecosystem Preservation-Theareas defined in accordance with Lawas protection and preservation should be excluded from the selection process andchoice of locations, except for the protection of spaces and environmental preservationcreated because of the deposit location.

The social economic aspects must include studies related with:

- Demographic survey - Demographic and its projection study;

- Jurisdiction and Use of Land and Water- Current use and future land uses, taking into view the fruits present and extracted potential, respecting the urban policies, land and agrarian reform;

- AgropastoralActivities- Evaluation the agropastoral activities of theselected areas;

- Industrial and Commercial Activities - Evaluationof existing activities in the region andthose that might result from the deposit location;

- Ways and Means Transportation- Spaceseasily accessible by the existing transport routes, appropriate means of transport, in accordance with the provisions of the standards for transport of radioactive materials existing in the country; 
- Public Lands- Surveyof public lands considering that the selected locals chosen should preferably be located in spacesbelonging to states and municipalities;

- Direct and indirect benefits to the surrounding population- Prevision of direct and indirect benefits due to the location of the deposit, which can be earned by the surrounding population.

The geological characterization must include the following studies:

- Availability, location and movement of surface and groundwater;

- Soilproperties;

- Tectonic and other processes that could cause breaks in the field;

- Mineralogical and chemical.

In physiographic terms, data collection and information studies should address:

- Hydrographic;

- Meteorologicalandclimatological.

However, as stated earlier, CNEN so far not published a standard focused for selecting sites for the disposal of high-level waste.

On the site selection process with should be also taking into account the established in the Agenda 21 Programme, that resulted from the well-known Earth Summit (Rio-92), which brought together 102 heads of states, especially in its chapter 22 that: "Governments should refrain from promoting or allow the storage or disposing of radioactive wastes near the marine environment, regardless of their level of radioactivity". It should also be emphasized that Brazilian President signed, on 26 January 1997, a Decree creating the Agenda 21 Sustainable Development Commission.

\section{GEOLOGICAL ENVIRONMENTS AS REPOSITORIES FOR RADIOACTIVE WASTES}

The disposal of high-level radioactive waste of high activity, according to Martins \& Bastos (1978)is the most serious problem that the nuclear industry should solve.

Raduan (1994) evaluated, as the IAEA, the geological formations as the most suitable for the isolation of high-level waste (containing radionuclides with long half-life, transuranic radionuclides, etc.).

Considering the approach adopted for many countries for the management of their high-level waste, the geological formations are the major source widely used today for the safe disposal of them. 
Wastes of high activity, according to Enokihara (1983)contain essentially all the non-volatile fission products and transuranic elements, approximately $0.5 \%$ uranium and plutonium initially found in spent fuel. Of the various types of waste produced in the recycling of uranium in the fuel cycle, high activity waste, althoughconstitute a small fraction of the total volume of waste generated, require greater protection and heat dissipation to provide maximum safety during storagein pools.

Although there are several concepts about the isolation of some radioactive waste from the biosphere, for the necessary long period, Enokihara (1983) noted that the only alternative that seems viable, from various points of view, is its storage in deep geological formations whose main attraction is the fact that many geological formations remained stable for millions of years. In addition, geological formations hold the three basic requirements that are critical to the safe disposal of radioactive materials:

- Cooling (rock acts as a heat sink, providing cooling);

- Protection (the depth of deposition provides adequate protection against radiation);

- Insulation (the size and integrity of formations allows the isolation, avoiding the escape material to the biosphere).

The geological formations considered more appropriate for the deposition of highlevel waste are the rock salt, granite, shale, carbonate and metamorphic rocks such as those in the Precambrian. Among all, the rock salt is considered as the optimal formation, although other rocks may, in ideal conditions, provide adequate isolation.

According to IAEA (2009), some wastes require a deep geological disposal to avoid problems to the environment and society. Among these wastes, we can highlight those involved in the nuclear fuel cycle, including the irradiated fuel used in the power generation process (high-level waste).

The safety of a geological repository according to the IAEA (2009)is based on the concepts of defense in depth and isolation that is provided by the combined effects of using multiple artificial and natural barriers.

In addition to the properties of the host rock, the specific aspects of the project and the degree of filling and sealing the openings and connections to the surface are highly relevant. Furthermore, certain design features, such as special waste containment (package) are clearly beneficial. Considering the geological aspects and their respective importance for the safe storage of radioactive waste, the IAEA noted that:

- Hard rocks (granites, for example) are effectively self-sufficient, and it is only necessary small measures of engineering and maintenance to avoid bankruptcy of the rock walls in the cells deposition and access points; 
- The argillaceous rock formations in France, Canada and Switzerland are highly consolidated sediments. These formations have high mechanical strength, depending on the structure and mineralogy rock. However, they may exhibit plastic behavior that although reducing the number of fractures in the rock, can also cause damage in the repository excavation areas.

In the United States, one of the most controversial and known projects is the Yucca Mountain nuclear waste repository, aimed at creating a deposit in the state of Nevada for the American high-level waste produced in the country. However, this situation has been the subject of disputes and discussions in Congress and in the Nuclear Regulatory Committee (NRC), the American regulatory body in the nuclear field.

The Eletronuclearstate company responsible for the operations of the nuclear reactors in the country (2010)pointed out that the final solutions for the high-level waste do not exist because they are not immediately necessary. According to them from the perspective of technology and cost, they are already viable for a long time but political reasons and prospects for future use of the spent fuel elements have delayed its effective implementation in the world. The fact is that site selection for geological disposal is a very complex issue not only dependent on political decisions but dependent on budget (very high cost) and it is also necessary to involve many experts from many technical fields including the elaboration of correct standards and the elaboration of a specific standard format for the safety assessment report which is not an easy task.

Currently, all the spent fuel produced in the CNAAA - Almirante Álvaro Alberto Nuclear Power Plants Angra 1 (since 1982) and Angra 2 (since 2001) are stored in pools, on a provisional basis, as shown in Table 3.There are currently 121 fuel elements in Angra 1 reactor core and 650 spent fuel in the pool.In Angra 2 there are 193 elements in the reactor core and 328 spent fuel in the pool (Table 3).

Table3. Spentfuelinventory.

\begin{tabular}{c|c|c|c|c}
\hline \hline \multirow{2}{*}{ StoragePlace } & \multicolumn{2}{|c|}{ Angra 1 } & \multicolumn{2}{c}{ Angra 2 } \\
\cline { 2 - 5 } & Capacity & Ocupation & Capacity & Ocupation \\
\hline \hline New StoragePlace & 45 & 0 & 75 & 0 \\
Region1 ofthe pool & 252 & 142 & 264 & 47 \\
Region2 ofthe pool & 1000 & 508 & 820 & 281 \\
Reactor Core & 121 & 121 & 193 & 193 \\
\hline \hline
\end{tabular}

It should be pointed out that the spent fuel storage capacity of Angra1 pool is enough for the entire operational life of the plant, while the storage capacity of spent 
fuel elements from the Angra 2 pool is just enough to fifteen years ( 14 cycles) which means that an additional solution must be provided urgently by Eletronuclear (ETN) in order to accommodate all the fuel elements that will be generated after the fourteenth cycle.

In the US, about 70,000 tons of spent nuclear fuel are currently stored in 131 places in 31 states. The Brazilian Nuclear Program Development Committee has set a target that an Intermediate LongStorage Deposit - DILD for the spent fuel elements must be construct in the country until 2026. The DILD will be designed, constructed and operated to technically ensure safe storage - that is, isolation from the public and the environment and to be implemented for a period not less than 500 years (Eletronuclear, 2010)which of course is not a sound option.

Considering the Brazilian case, with the expansion of nuclear power stations located in Angra dos Reis, state of Rio de Janeiro, especially with the construction of Angra III, and with the prospect of building 4-8 new nuclear reactor plants on the horizon by 2030 in Brazil territory. As noted Silva (2013), the issue of selection of sites for the construction of repositories for thenational high-level radioactive wastes generated in the country is a very relevant theme and will require the development of standards aimed to facilitate the proper choice of locations for its deposition.

\section{GEOLOGICAL CHARACTERISTICS OF RIO DE JANEIRO STATE}

The state of Rio de Janeiro has a diverse geological characterization, whose studies of its characteristics can indicate potential sites for high-level radioactive waste disposal, especially because the nuclear powers plants complex of Angra dos Reis is located in Rio's southern region.

The diversity of rocks that make up the regional substrate state as well as its geological characteristics, including degrees of fracturing, seismicity, thickness and composition of the soil cover, hydrological characteristics, urban and rural occupation studies are important parameters to be considered in the selection of suitable sites for the safe disposal of radioactive waste and will be the focus of this study.

\section{The Studied Area}

The research will cover the territory of the state of Rio de Janeiro (Figure 1) and based on the geological information map in scale 1: 400,000, prepared by the Department of Geology from the State University of Rio de Janeiro State - UERJ (where this project is being developed), the main parameters and criteria's will be 
identified for the appropriate choice of sites aimed for the disposal of the high level waste from the nuclear power plants of Angra dos Reis.

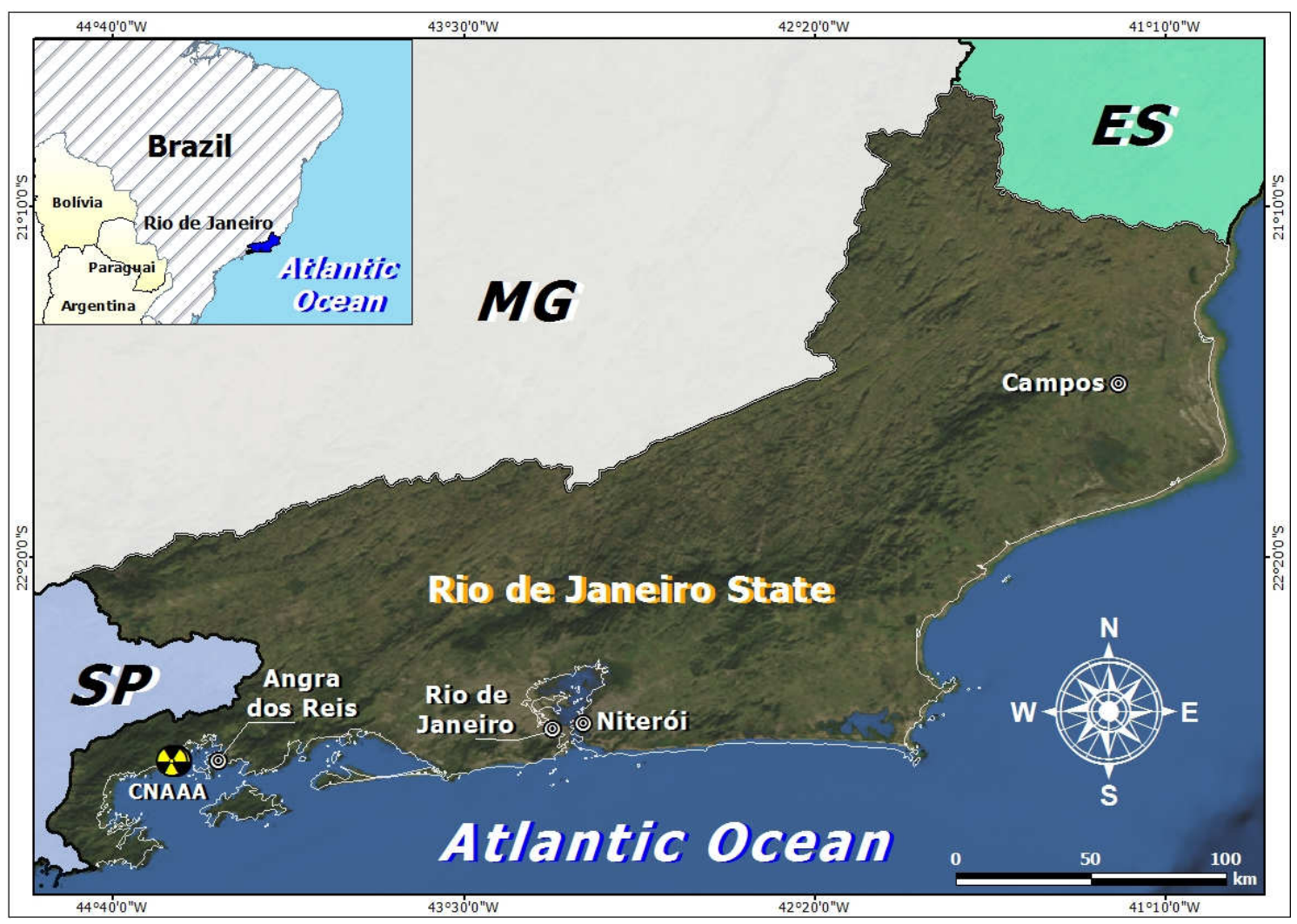

Figure 1. Area of Research.

In geological terms, the State of Rio de Janeiro, according CPRM (1998), has the following characteristics:

- Is geotectonically contained in Mantiqueira Province, according to the definition of Adams et al. (1981), an entity that covers a large area (approximately $700,000 \mathrm{~km}^{2}$ ) and is South America's most complex structural province affected by Orogenic Cycle Neoproterozoic/Cambrian (Brasiliano), extending parallel 33S, Uruguay, to the south of Bahia, in parallel 15S, for about $3000 \mathrm{~km}$ in length and average width of $200 \mathrm{~km}$. It is arranged parallel to the Brazilian coast, along the eastern shores of the Rio de La Plata cratons and San Francisco;

- The Mantiqueira Province represents a tectonic entity with free guidance northeast installed west of Craton the end of the Neoproterozoic and early Paleozoic, constituting together with the Brasilia Strip, the wedge Guaxupé and metasediments of the named range Upper Rio Grande, the tectonic framework of the Southeastern Brazil;

- Due to its privileged geographical position, flanking the South American continent and facing the southeast of the African continent, this province constitutes a key element for understanding the Neoproterozoic collage of orogensBrasiliano/Pan- 
African following the convergence of previously dispersed Supercontinent Rodinia fragments during the amalgamation of Western Gondwana Supercontinent;

- From the second half of the $80 \mathrm{~s}$, with the increase of systematic mapping work and using new concepts and methods, several authors have proposed different models, since with a current view based on plate tectonics to explain the genesis and the relationship between the different outcrop units in the state, deformation and metamorphism printed in regional units as well as the abundant granite magmatism throughout the state;

- Several works of regional nature postulate that the tectonic-thermal characteristics of the province are the result of subduction processes, followed by one or more collisions in the Neoproterozoic, when the assemblage or collage of West Gondwana (eg Machado et al., 1996).

\section{MATERIALS AND METHODS}

The methodological procedures used for this research include the selection and main aspects/factorsthat must be considered for choosing areas for the disposal of high-level wastes including the use of geo-technology.

\section{Factors to be Considered for the Choice of Radioactive Waste Geological Deposits Areas}

Although some basic geological characteristics point's favorable conditions for the construction of radioactive waste repositories, this assessment must be accompanied by other factors which, according to Gray et al. (1976)include:

- Lithology and spatial distribution of the geological formation;

- Physical-chemical characteristics of the formation in relation to waste properties and packages;

- Hydro-geologicalconditions;

- Climatechangeeffects;

- Infiltration routes to the surface;

- Engineeringfeasibility;

- Interaction between the various criteria;

- Identification of the all systems to which the area may be subject in the following. 100,000 years. 
In this perspective, Tammemagi (1976), in a program developed by Canada listed three groups of factors that should be considered when choosing radioactive waste deposits as follows:

Local and Environmental Factors: Seismicity; Population and industrial density; Access to the area; Topography; Hydrology; Geological long-term changes, such as glaciation and oscillation of the sea level.

Factors Related to Mass and Rocky Substance: Homogeneity and extent of formation; Occurrence and character of larger structures; Existence of discontinuities; Petrological and mineralogical composition; Ion exchange properties; Permeability and porosity; Economic value; Thermal properties such as conductivity and expansion; Mechanical properties such as strength and modulus of elasticity; Physicochemical properties; Response to radiation.

Legal and Political Factors: Land ownership; Existing rights; Possible conflicts with other demands on land use; Site security; Property of the waste; Repository property.

\section{Geotechnologies as a Support for an Integrated Environmental Tool Management}

With the advent of new information technologies, diverse computing platforms, including GIS (Geography Information System) have emerged and is continuously and increasingly being use to assist in scientific, technical and academic learning and development. In the present approach, it is demonstrated the importance of the development of an integrated platform in a GIS environment, with information covering different aspects/factors, representative of the environmental choosing process of areas for repositories for high-level wastes including the most important data related to geological and environmental information of the areas of interest of the study.

Such approach allows a systemic view about the problem. In this sense, the application of digital technologies of GIS and the creation of databases and an integrated information platform about the geological aspects for the choice of repositories for high-level nuclear waste in the State of Rio de Janeiro is justified by the existing geological framework, represented by the geological map of the State of Rio de Janeiro in 1: 400,000.

Socio environmental maps that will be prepared during the project will empower the evaluation of interrelationships that needs to be consider when choosing appropriate facilities and locations for waste disposal, and should point the main constraints that need to be analyzed in such studies and especially the planning and management of land use in the geographical space/places of interest. 
The structured SIG will allow evaluating the relative importance of all variables usedand in addition to treatand evaluate the various data on the environment, population and other related aspects. From these analyzes and correlations, it is expected to obtain an objective and integrated tool that based on indicators and interactive maps indexes, that can support the decision-making process of the regulatory bodies and municipalities involved, seeking to minimize the impact on human life and environment due to the disposal of radioactive waste.

\section{RESULTS}

A database is being developed for the study area and consists of a GIS database featuring the various aspects considered in the survey. Figure 2 presents an overview of the structure of the GIS system that has been prepared and table 5 shows the set of information that is being incorporated in the information system adopted.

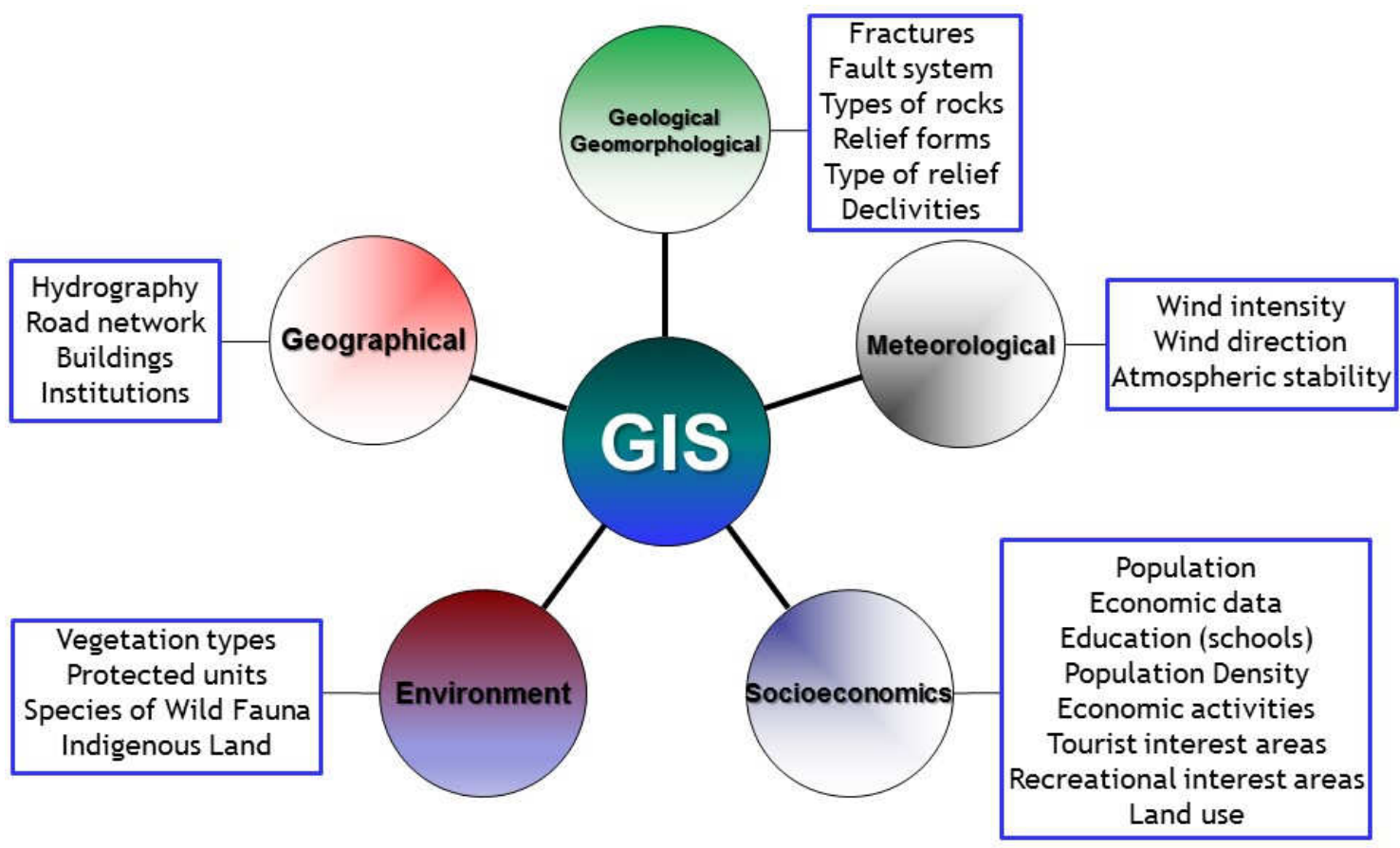

Figure 2. Structure of the GIS system under development. 
Table5. Attributes and information incorporated into the GIS database.

\begin{tabular}{|c|c|c|}
\hline Topic & Atribute & Information \\
\hline \multirow{4}{*}{ Geograph data } & Territorial division & $\begin{array}{l}\text { States } \\
\text { Municipalities } \\
\text { Municipal offices }\end{array}$ \\
\hline & $\begin{array}{l}\text { Hydrographic } \\
\text { network }\end{array}$ & $\begin{array}{l}\text { Hydrograpy } \\
\text { Water bodies } \\
\text { Hydrographic basin } \\
\text { Water Collection Points }\end{array}$ \\
\hline & Road System & $\begin{array}{l}\text { Highway network } \\
\text { Railway Network }\end{array}$ \\
\hline & Important Points & $\begin{array}{l}\text { Buildings } \\
\text { Institutions } \\
\text { Industries } \\
\text { Schools } \\
\end{array}$ \\
\hline \multirow[t]{2}{*}{$\begin{array}{l}\text { GeologicalandGeomorphological } \\
\text { data }\end{array}$} & Geology & $\begin{array}{l}\text { Fault system } \\
\text { Fractures } \\
\text { Types of rocks } \\
\text { Hydrogeology } \\
\end{array}$ \\
\hline & Geomorfology & $\begin{array}{l}\text { Relief form } \\
\text { Slopes } \\
\text { Types of soil }\end{array}$ \\
\hline Meteorological data & Meteorology & $\begin{array}{l}\text { Wind intensity } \\
\text { Wind direction } \\
\text { Atmospheric stability }\end{array}$ \\
\hline \multirow{4}{*}{ Socioeconomic data } & Population & $\begin{array}{l}\text { Total inhabitants } \\
\text { PopulationDensity }\end{array}$ \\
\hline & Economy & Economicactivities \\
\hline & $\begin{array}{l}\text { Economic Areas of } \\
\text { Interest / Turístico }\end{array}$ & $\begin{array}{l}\text { Agricultural cultivation } \\
\text { areas } \\
\text { Fisheries } \\
\text { Tourist interest areas } \\
\text { Recreationalinterestareas }\end{array}$ \\
\hline & Land use & Land use andoccupation \\
\hline Environmental Data & $\begin{array}{l}\text { Environmental } \\
\text { Restrictions }\end{array}$ & $\begin{array}{l}\text { Vegetation types } \\
\text { Protected areas } \\
\text { Indigenous land } \\
\text { Animal species } \\
\end{array}$ \\
\hline
\end{tabular}

Considering the possible areas of interest to be located in the state of Rio de Janeiro, these attributes can also incorporate other elements rated as important on the point of view of an integrated analysis.

\section{CONCLUSIONS}

The construction of a geographic database on the topic of interested and the access to the scientific community contributes to the dissemination of knowledge and deepening of this subject in the scientific community. Associated to the problem to be solved, supports to expand the range of discussions involving the complexity of the final destination of the high-level radioactive waste generated in the country. In this sense, evaluations and specific analysis of the project under development will allow to list and identify factors and aspects related to the topic. 
In environmental terms, identifying potential safety areas for the correct disposal of the Brazilian high-level radioactive waste is a very importantissue specially taking into consideration the dangerous of this type of waste that remains radioactive for a long period of timeand that is generated by the nuclear power activity in the State of Rio de Janeiro and in the future in many other states.

From the scientific point of view:

- The development of the project allows a better understanding of the problem associated to the disposal of high-level radioactive waste and the importance of geological studies for this purpose;

- Better understanding regarding the safety criteria that must be adopted in the choice and management of radioactive waste;

- Validation of a methodology for selecting areas through digital technologies of GIS, including GIS and remote sensing;

- Understanding of the geological scaleswith the relevant aspects of the selected areas and their possible use as radioactive waste repositories.

On social terms:

- Information about land use and reorganization may contribute to the management of selected areas;

- Environmental education to the public, with environmental and nuclear information about the problems available in a transparent form;

- Integration of research institutions and management agencies of nuclear waste with the local people.

In technological terms, we can cited the validation of a GIS system for applications in environmental issues especially in the nuclear area. The development of a specific database on the subject, as well as integrated spatial analysis, where data and information, especially geological, will help to characterize the complexity of the site selection process. Thus, the universal character of such technologies allows replicate the actions in other regions of interest, whether in regional or national level. In this sense, a GIS system, representing the diversity of geographical space, integrating data and environmental information willresult in a good geographic database for the region allowing other desires uses.

\section{REFERENCES}


Almeida, F.F.M de; Hasui, Y.; Brito Neves, B.B.; Fuck, R.A. 1981. Brazilian structural provinces:an introduction. Earth Science Rewiew,17: 1-29.

CNEN - Comissão Nacional de Energia Nuclear. 1989. Norma CNEN-NE 6.06, "Regulation on Selection and Choice of Sites for Radioactive Waste Disposal Facilities", Brazilian Nuclear Energy Commission, (in Portuguese).

CPRM - Companhia de Pesquisa e Recursos Minerais. 1998. Geologia Do Estado Do Rio de Janeiro. Programa Levantamentos Geológicos Básicos do Brasil. Projeto Rio de Janeiro - Geologia.

Eletronuclear. 2010. Temas Gerais: Rejeitos, Disponível em http://www.eletronuclear.gov.br/perguntas respostas/perguntas respostas.php?id cat egoria $=4 \&$ id subcategoria $=17$.

Enokihara, C.T. 1983. O Armazenamento de Rejeitos Radioativos no Brasil, com Ênfase Especial em Rochas, IPEN, São Paulo.

Gray, O.A. et al. 1976. Disposal of highly active, solid radioactive wastes into geological formations - Relevant geological criteria for the United Kingdon. Abstract. IGS-76/12.

Heilbron P.F.L., Tranjan A., Rochedo E. and Malamut C. 1994. "Safety Analysis Report on Large Size Waste Container" (in portuguese), Coordenação de InstalaçõesNucleares e Radiativas - Comissão Nacional de Energia Nuclear.

Heilbron P.F.L., Rochedo E. and Xavier A.M. 1996. "Preliminary Safety Assessment of the First Brazilian Repository", Proceedings of an International Symposium on Experience in the Planning and Operation of Low Level Waste Disposal Facilities". International Atomic Energy Agency, 17-21, June.

International Atomic Energy Agency (IAEA). 1981. Underground Disposal of Radioactive Wastes. Safety Series 54 - Basic Guidance - IAEA, Vienna.

International Atomic Energy Agency. 1987. Code of Federal Regulation - 10 CFR (Parts 0-199), Revised as of January.

International Atomic Energy Agency. 1987. Regulatory Objectives, Requirements and Guidelines for the Disposal of Radioactive Wastes, Long-Term Aspects. Regulatory Document R-104, Atomic Energy Control Board, Canadá.

International Atomic Energy Agency. 1989. Guidance for Regulation of Underground Repositories for Disposal of Radioactive Wastes. Safety Series No 96, IAEA, Vienna. International Atomic Energy Agency. 1994. "Siting of Geological Disposal Facilities" (111-G-4.1), Vienna, Austria.

International Atomic Energy Agency. 1995. Safety Series 111F - "The Principles of Radioactive Waste Management", Vienna, Austria. 
International Atomic Energy Agency. 2003. Safety Standard Series No WS-G-2.6 "Predisposal Management of High Level Radioactive Waste", Safety Guide, Vienna, Austria.

International Atomic Energy Agency. 2006. "Geological Disposal of Radioactive Waste" - (WS-R-4), Vienna, Austria.

International Atomic Energy Agency. 2009. Geological disposal of radioactive waste: technological implications for retrievability, IAEA, Vienna.

Machado N., Valladares C., Heilbron M., Valeriano C. 1996. UPb geochronology of the central Ribeira belt (Brazil) and implications for the evolution of the Brazilian Orogeny. Precambrian Res., 69:347-361.

Martins, L.A.M.\&Bastos, J.P.C. 1978. Disposição de Rejeitos Radioativos de Alta Atividade em Formações Geológicas. Anais do $2^{\circ}$ congresso Brasileiro de Geologia de Engenharia. Associação Brasileira de Geologia de Engenharia. Vol. 2. São Paulo, Nov. 1978.

Raduan, R.N. 1994. Requisitos Ambientais para Disposição Final de Rejeitos Radioativos em Repositórios de Superfície. Dissertação de Mestrado. IPEN (Instituto de Pesquisas Energéticas e Nucleares). 185 p. São Paulo.

Silva, C. 2013. "Modelagem Lagrangeana da Dispersão Atmosférica de Radionuclídeos e Sistemas de Informação Geográfica como Ferramentas de Suporte ao Planejamento de Emergência na Área de Influência do Complexo Nuclear de Angra dos Reis - RJ". Tese de Doutorado, Programa de Engenharia Civil. UFRJ. COPPE. Rio de Janeiro.

Tammemagi, H.Y. 1976. Geological disposal of radioactive wastes - The Canadian Development Program. AECL-5392. 20 p.

\section{Acknowledgements}

The authors would like to thank the institutional and financial support of the Foundation for Research of the State of Rio de Janeiro (FAPERJ), plus the contributions of the editors and reviewer

Recebido: 29/05/2015

Aprovado: 28/06/2015 